\title{
Pemetaan situasi dan kondisi kebahasaan dalam mendukung keberhasilan program BIPA di Timor Leste
}

\author{
Tri Amanat *), \\ Pusat Pengembangan Strategi dan Diplomasi Kebahasaan \\ *) Correspondences author: Kawasan Indonesia Peace and Security Center (IPSC), Jalan Anyar Km. 4, Sukahati, Citeureup, \\ Bogor, Jawa Barat 16810, Indonesia; \\ e-mail: tri.amanat@kemdikbud.go.id
}

\begin{abstract}
One step to improve the function of Indonesian language into an international language is done through the development of Indonesian language teaching programs for foreigners (BIPA) in various friendly countries, including Timor Leste. Until now Timor Leste is one of the countries with the most requests for sending BIPA teachers. Therefore certain steps are needed to support the success of this program, one of which is by conducting a study related to the situation and conditions of the language. This study aims to; Describe the situation and conditions of language that exists in Timor Leste both in the realm of government policy and the real conditions that exist in society. Mapping the potential and barriers to the development of Indonesian in East Timor. This study uses qualitative methods. Data acquisition is done through document analysis, field observations, and interviews. The results of the study indicate that East Timor is a multilingual community. In macro terms, there are several regulations that can support the development of BIPA, however, there are also some that can hamper. In micro terms, Indonesian is still considered familiar by certain groups but in general, the younger generation of Timor Leste (especially those born after independence) have many who do not understand/know bahasa Indonesian.
\end{abstract}

Key Words: language policies, mapping of linguistic situations, BIPA programs in Timor Leste.

This work is licensed under a Creative Commons Attribution-ShareAlike 4.0 International License

\section{Pendahuluan}

Pusat Pengembangan Strategi dan Diplomasi Kebahasaan (PPSDK), sebagai salah satu satuan kerja di bawah Badan Pengembangan dan Pembinaan Bahasa Kementerian Pendidikan dan Kebudayaan, memiliki tugas dan fungsi untuk melakukan penginternasionalan bahasa Indonesia, sebagaimana tercantum dalam Peraturan Pemerintah Nomor 57 Tahun 2014 dan Rencana Strategis (Renstra) PPSDK Tahun 20152019. Tugas dan fungsi tersebut dijalankan, salah satunya melalui kegiatan pengiriman tenaga pengajar BIPA ke luar negeri. Kegiatan ini penting dilakukan sebagai bentuk amanat peraturan perundanganundangan dan peningkatan fungsi bahasa Indonesia menjadi bahasa internasional.

Peningkatan fungsi bahasa Indonesia menjadi bahasa internasional dilakukan melalui (a) penggunaan bahasa Indonesia di forum internasional, (b) pengembangan program pengajaran bahasa Indonesia untuk orang asing, (c) peningkatan kerja sama kebahasaan dan kesastraan dengan pihak luar negeri, dan (d) pengembangan dan pemberdayaan pusat pembelajaran bahasa Indonesia di luar negeri (PP Nomor 57, Tahun 2014, pasal 31, ayat 1). Tercatat sejak tahun 2015-2017, PPSDK telah mengirimkan 288 tenaga pengajar BIPA ke berbagai negara misalnya; Timor Leste, Thailand, Malaysia, Mesir, Tunisia, dan sebagainya.

Namun demikian, sampai saat ini belum ada kajian komprehensif dan akurat mengenai kondisi dan situasi kebahasaan di negara sasaran. Padahal, data tersebut sangat diperlukan dalam menunjang penentuan strategi atau langkah-langkah yang dianggap paling akurat dan efektif dalam usaha penginternasionalan bahasa Indonesia di negara bersangkutan. Oleh karena itu, perlu dilakukan kajian untuk memberikan data kepada pihak-pihak terkait sebagai bahan rekomendasi untuk pengambilan kebijakan. Dengan mendasarkan kebijakan pada kajian ini, program-program pengembangan bahasa Indonesia di luar negeri diharapkan dapat lebih tepat sasaran dan mencapai target yang diharapkan. 
Lebih lanjut, kajian ini akan mengkaji tentang situasi dan kondisi kebahasaan negara Timor Leste. Pemilihan Timor Leste selain didasari pada jumlah permintaan dan pengiriman guru BIPA yang cukup banyak dibanding negara lain juga terkait dengan posisi, nilai historis, dan nilai strategisnya bagi Indonesia. Selain itu, sikap masyarakat dan pemerintah negara tersebut terhadap bahasanya maupun bahasa Indonesia juga perlu disinggung meski tidak secara khusus karena berpengaruh juga terhadap strategi yang nantinya disusun dalam proses internasionalisasi bahasa Indonesia di Timor Leste.

Dengan demikian kajian ini bertujuan untuk; 1. Mendeskripsikan situasi dan kondisi kebahasaan yang ada di Timor Leste baik dalam ranah kebijakan pemerintah maupun kondisi riil yang ada di masyarakat. 2. Memetakan potensi dan hambatan pengembangan bahasa Indonesia di Timor Leste.

Seperti yang telah disinggung di awal, kajian ini diharapkan dapat menjadi bahan rekomendasi bagi pengambil kebijakan dalam menentukan langkah dan arah pengembangan internasionalisasi bahasa Indonesia di masa depan, khususnya di wilayah Timor Leste. Kajian ini juga diharapkan dapat mendorong lahirnya kebijakan-kebijakan yang berdasar kajian di bidang pengembangan strategi untuk diplomasi kebahasaan yang dapat memberikan landas pijak bagi penentuan kebijakan yang komprehensif dan tepat sasaran.

Belum banyak kajian yang membahas mengenai strategi kebahasaan khususnya dalam rangka internasionalisasi bahasa Indonesia. Namun, ada sebuah kajian yang dapat dijadikan referensi secara teoritis yaitu, kajian mengenai perencanaan bahasa Indonesia yang dilakukan oleh Moeliono (1981). Dalam kajiannya yang berjudul Pengembangan dan Pembinaan Bahasa: Ancangan Alternatif di dalam Perencanaan Bahasa, Moeliono membahas beberapa hal yang berkaitan dengan perencanaan bahasa dan masalah kebahasaan lainnya, seperti kedudukan bahasa nasional, pembakuan bahasa, dan ketidakpadanan di dalam pemakaian bahasa. Dalam kajian tersebut, Moeliono mengajukan sebuah ancangan alternatif yang dapat digunakan dalam perencanaan bahasa.

\section{Metode}

Kajian ini menggunakan metode kualitatif. Pendekatan kualitatif digunakan untuk mengkaji situasi dan kondisi kebahasaan yang ada di Timor Leste baik dalam ranah kebijakan pemerintahnya maupun kondisi riil yang ada di masyarakat. Kemudian memetakan potensi dan hambatan pengembangan bahasa Indonesia di Timor Leste. Pendekatan kualitatif dalam kajian ini dilakukan melalui metode yang utama dengan analisis dokumen, serta didukung dengan observasi lapangan, dan wawancara sebagai upaya konfirmasi data yang diperoleh. Namun dalam pembahasannya ketiga sumber data tersebut tidak pisahpisahkan karena masing-masing sumber data bisa berfungsi saling menguatkan.

Kajian ini dilaksanakan di negara Timor Leste khususnya di ibu kotanya, Dili pada rentang waktu Maret sampai dengan Juni 2018. Selain aspek keterjangkauan, pemilihan Dili juga disandarkan pada jumlah penduduk dan komposisinya yang telah dianggap dapat mewakili keseluruhan wilayah-wilayah yang ada di Timor Leste. Selain itu hingga kini Dili merupakan satu-satunya tujuan urbanisasi penduduk dengan beragam motif seperti melanjutkan pendidikan, perdagangan, dan lain sebagainya. Partisipan kajian ini terdiri atas informan yang berasal dari berbagai lapisan masyarakat di Timor Leste.

Teknik pengumpulan data dalam kajian ini meliputi; 1. Analisis dokumen, analisis dokumen dilakukan terhadap dokumen yang memuat berbagai informasi terkait kebahasaan di negara Timor Leste. Analisis ini digunakan untuk mendapatkan informasi sebanyak-banyaknya mengenai kegiatan perencanaan dan kebijakan bahasa di negara tersebut, baik yang terdapat pada dokumen-dokumen resmi pemerintah atau lembaga, laporan, selebaran, poster, situs internet maupun literatur yang berkaitan dengan tujuan kajian. 2 . Observasi lapangan, metode observasi digunakan untuk memperoleh jawaban yang utuh dan menyeluruh dari pertanyaan-pertanyaan kajian. Dalam kajian ini, observasi tehadap kondisi-kondisi di lapangan diperlukan untuk mengonfirmasi jawaban-jawaban informan terkait perilaku berbahasa dan sikap bahasa masyarakat negara Timor Leste terhadap bahasa yang ada serta peluang dan tantangan pengembangan bahasa Indonesia di negara tersebut. 3.Wawancara, wawancara dirancang dalam bentuk wawancara bebas namun dengan pertanyaan-pertanyaan yang mengggali jawaban yang diperlukan sesuai dengan tujuan kajian. Partisipan yang dipilih untuk diwawancarai meliputi kalangan masyarakat dan pihak-pihak yang dianggap berpengaruh baik dalam pengambilan kebijakan kebahasaan di Timor Leste maupun sebagai anggota masyarakat dan pihak terdampak kebijakan tersebut. 
Analisis data kajian ini dilakukan secara kualitatif. Analisis data dengan mengikuti model Miles dan Huberman (2014) yang terdiri atas reduksi data, penyajian data, dan penarikan simpulan. Tahapan analisis data kualitatif meliputi (1) mentranskripsikan data hasil analisis dokumen, wawancara dan catatan lapangan (observasi), (2) melakukan identifikasi dan deskripsi terhadap data, (3) menyajikan data yang telah diklasifikasi, dan (4) menyimpulkan hasil interpretasi data berdasarkan fokus penelitan.

\section{Pembahasan}

\section{A. Situasi Kebahasaan Timor Leste}

Pemerintah Timor Leste menyatakan ada 32 bahasa asli yang tersebar di seluruh wilayahnya (Livru Sensus, 2015). Sedangkan menurut Survei Linguistik Timor Timur (Hull 1998: 4) mengklasifikasikan varietas tertentu hanya sebagai dialek dari kelompok 16 bahasa lainnya. Bahasa-bahasa yang tersebut sebagian merupakan rumpun Austronesia sedangkan sebagian lainnya adalah rumpun Melanesia. Hal itu menunjukkan bahwa banyaknya gerakan migrasi penduduk yang kompleks selama kurun berabad-abad lampau.

Timor Leste termasuk wilayah dengan sejarah panjang kolonialisme dan multilingualisme. Masa kolonialisme Portugis selama lebih dari empat abad (1500an-1975) di wilayah ini juga mengukuhkan keberadaan bahasanya, bahkan banyak kosakatanya yang diserap dalam bahasa yang paling banyak pemakainya yaitu, bahasa Tetum. Bahasa Tetum sendiri memiliki beberapa varian seperti Tetum Praça (juga dikenal sebagai Tetum-Dili) diucapkan di dalam dan di sekitar ibu kota dan memiliki jumlah penutur terbanyak. Kemudian ada Tetum-Terik (dikenal juga sebagai Tetum lama) yang dianggap sebagai dialek kelas tinggi. Dan varian ketiga, Tetum-Belu, yang banyak digunakan di perbatasan dengan wilayah Indonesia. Bahasa Tetum Praça kini telah ditetapkan sebagai standar bahasa resmi negara di Timor Leste dan telah memiliki ortografi dan tata bahasa tulis resmi. Selain itu ditemukan juga pemakaian bahasa Melayu dan China.

Keberadaan Indonesia selama 24 tahun (1976-1999) juga memberi pengaruh yang kuat terhadap perubahan situasi kebahasaan di Timor Leste. Peraturan kewajiban menggunkan bahasa Indonesia pada level dan even tertentu serta pelarangan penggunaan bahasa Portugis pada masa itu sangat mempengaruhi jumlah pemakaian bahasa-bahasa yang ada, dan masih dirasakan hingga kini. Masa transisi menjelang kemerdekaan pada awal abad 21 yang membuat PBB dan banyak NGO internasional terlibat di Timor Leste juga membuat warga bangsa ini mengenal dan mulai tertarik mempelajari bahasa Inggris, hal itu juga semakin menegaskan situasi bahasa yang multilingual di wilayah ini.

Para diaspora yang meninggalkan Timor Leste karena persoalan politik banyak tersebar diberbagai negara seperti, Portugal, Mozambik, Angola, Tanjung Verde, Australia, Amerika Serikat, Amerika Serikat dan Irlandia kini banyak yang kembali dengan kemampuan bahasa asingnya juga ikut memberikan warna multilingual yang ada termasuk para pelajar yang banyak belajar di Indonesia dengan kemampuan berbahasa Indonesia maupun beberapa bahasa daerah di sana.

Pada kajian ini bahasan mengenai ranah kebahasaan di Timor Leste secara garis besar dapat dibagi menjadi dua lingkup yaitu; 1. Lingkup makro atau tataran kebijakan kenegaraan/pemerintahan, dan 2. Lingkup mikro atau tataran kondisi riil di masyarakat namun, sebelumnya perlu dipahami sebagai sebuah negara baru yang mempunyai masa lalu kolonialisasi yang lebih dari 500 tahun di bawah Portugis dan 24 tahun di bawah Indonesia menimbulkan suatu kerancuan identitas masyarakatnya. Oleh karena itu pembentukan suatu identitas sebagai sebuah bangsa sangat diutamakan oleh negara termiskin ke 7 di dunia ini. Proses pembentukan kebijakan tersebut termasuk dalam hal kebahasaan. Untuk membahas hal tersebut perlu ditinjau dari segi latar belakang kondisi sosial, demografi dan geopolitik masyarakat Timor Leste.

Ketika kajian ini dilakukan masyarakat Timor Leste dapat dibagi ke dalam lima golongan sebagaimana diilustrasikan dalam gambar berikut ini; 


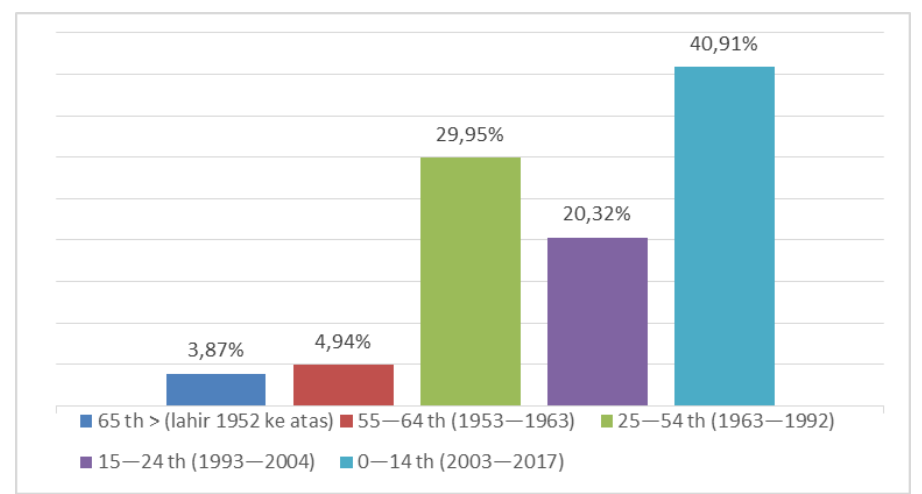

Keterangan: (Diolah berdasar data CIA world Fact Book (2017))

Dengan menyimak piramida penduduk Timor Leste di atas terlihat bahwa yang kini (awal 2018) masih menjadi elit politik dan penentu kebijakan pemerintah Timor Leste, yang berkecimpung di parlemen dan pemerintahan adalah golongan 1 dan 2 . Meski secara jumlah mereka adalah yang paling sedikit diantara komposisi penduduk Timor Leste saat ini, namun peran mereka masih yang terbesar di Timor Leste baik pra maupun pasca kemerdekaan bahkan hingga saat ini. Merekalah pelaku sekaligus saksi sejarah yang masih hidup sehingga sangat dihormati dan ditaati oleh golongan-golongan yang lebih muda. Golongan 1 dan 2 inilah penentu semua kebijakan yang kini berlaku di negara tersebut tentu saja termasuk termasuk kebijakan kebahasan.

Para elite politik yang berperan dalam penentuan kebijakan bahasa sebagaimana yang kemudian tertuang dalam konstitusi Timor Leste berada dalam badan-badan berikut,

1. Dewan Menteri (yang terdiri dari; Perdana Menteri, Deputi Perdana Menteri, dan menteri-menteri yang ada di kabinet),

2. Kementerian Pendidikan, Kebudayaan, Pemuda dan Olah Raga (Ministerio de Cultura, Juventude e Esporto/MECYS),

3. Dewan Hakim Agung, dengan dibantu Kementerian Keadilan),

4. 88 anggota Majelis Konstituen (sekarang menjadi Parlemen nasional),

5. Institut Linguistik Nasional (Instituto Nacional Linguistica/INL).

Sedangkan beberapa instrumen berupa dokumen/kebijakan yang berpengaruh terhadap perkembangan pembangunan identitas di Timor Leste melalui segi kebahasaan adalah sebagai berikut;

1. Konstitusi Nasional atau The National Constitution of 2002

2. Keputusan Bahasa atau Government Decree No. 1 of 2004: Orthographical Standard of the Tetum Language

3. UU Dinas Sipil No. 8/2004 atau Civil Service Law No. 8 of 2004

4. Arahan Kebahasaan atau The Language Directive of 2004

5. Kerangka Kebijakan Pendidikan untuk 2004-2008/The Education Policy Framework for 20042008

Hal yang paling nyata dari produk kebijakan kebahasaan yang dirumuskan oleh elit politik Timor Leste (dalam hal ini golongan 1 dan 2) adalah adanya pasal 13 dalam konstitusi Timor Leste tentang penentuan bahasa resmi dan bahasa nasional Timor Leste yang terdiri atas dua pasal, berbunyi;

1. Tetum dan Portugis adalah bahasa-bahasa resmi Republik Demokratik Timor-Leste.

2. Tetum beserta bahasa-bahasa nasional lainnya dihargai dan dikembangkan oleh Negara. Timor Leste.

yang dimaksud oleh bahasa-bahasa nasional dalam pasal dua adalah bahasa daerah yang ada di

Penentuan bahasa Portugis sebagai salah satu bahasa resmi tak lepas pula dari keanggotaan negara ini dalam Negara-negara Berbahasa Portugal/Comunidade dos Países de Língua Portuguesa (CPLP) yang terdiri; Portugal, Brasil, Angola, Vila Verde, Guinea-Bissau, Equatorial Guinea, Mozambique, São Tomé and Príncipe dan Timor-Leste sendiri. Sekalipun Bahasa Portugis di Timor-Leste menjadi Bahasa resmi, 
namun diperkirakan penduduk yang secara fasih menguasai bahasa Portugis hanyalah kurang dari 5\% dari total jumlah penduduknya (laporan pembangunan PBB, 2006), 15\% (dalam Golden, 2004), sedang menurut para anggota Instituto Nacional de Linguistica (Institut Linguistik Nasional Timor) yang didirikan oleh Universidade Nacional Timor Lorosa'e, Faculdade de Educacao Artes e Humanidades adalah 25\% penduduk Timor Leste. Penguasaan Bahasa Portugis sendiri hanya bagi kelompok masyarakat yang mengenyam pendidikan pada masa penjajahan Portugis sebelum tahun 1975 sedangkan kelompok mayoritas setelah tahun tersebut lebih familiar dengan Bahasa Tetum dan Bahasa Indonesia. Sebenarnya bahasa Tetum sendiri merupakan bahasa kreol, dengan jumlah kosakata yang masih sangat minim (Ethnologue, 2018). Sehingga mau tidak mau pengguna bahasa ini mengambil banyak kosakata serapan terutama dari bahasa Portugis dan Indonesia dalam berkomunikasi.

Pada kedua ayat pasal 13 Konstitusi RDTL tersebut secara jelas dapat dibaca arah ke depan kebijakan pemerintah Timor Leste dalam membentuk identitas masyarakat Timor Leste khususnya dalam ranah kebahasaan. Hal tersebut menimbulkan banyak permasalahan salah satunya dengan banyaknya pekerja yang kehilangan pekerjaan karena kualifikasinya tidak memenuhi tuntutan yaitu, harus berkemampuan bahasa Portugis. Peluang ini kemudian dimanfaatkan oleh pemerintah Portugal baik melalui CPLP ataupun melalui lembaganya, Instituto da Cooperacao e da Lingua dengan mendirikan Centro Cultura Portuguesa di Dili. Lembaga ini bertujuan untuk mendukung aksi-aksi budaya di TimorLeste khususnya budaya Portugis. Pembangunan ini ditujukan untuk memberikan ruang kepada anggota komunitas berbahasa Portugis agar dapat mengembangkan dan mempromosikan Bahasa Portugis di negara ini. Centro Cultura Portuguesa memiliki ruang multimedia dengan akses internet gratis serta perpustakaan multimedia yang memiliki koleksi film hingga 150 buah dengan jenis-jenis film seperti film dokumenter, film pendek dan film layar lebar.

Kebijakan Pemerintah Timor Leste sendiri terkait bahasa resmi lainnya yaitu, bahasa Tetum adalah melalui Universidade Nacional Timor Lorosa'e (UNTL/Universitas Negeri Timor Leste) dengan Faculdade de Educacao, Artes e Humanidades telah mendirikan Instituto Nacional de Linguistica pada pertengahan juli 2001. Didirikannya lembaga ini bertanggungjawab untuk pengembangan dan studi Bahasa Tetum dan Bahasa daerah lainnya yang digunakan di Timor-Leste. Program-program yang dilaksanakan di lembaga ini diantaranya: pembuatan kamus Tetum Nasional, Standar Ejaan, Rekaman Orthografi Tetum, Tata Bahasa Tetum Resmi, Profil Bahasa Lokal dan Artikel. Pernyataan mengenai penentuan bahasa resmi tersebut sangat berpengaruh terhadap komposisi perkembangan dan pemakaian bahasa-bahasa utama yang sebelumnya telah digunakan oleh masyarakat Timor Leste.

Keputusan Pemerintah No. 1 Tahun 2004 (dikenal sebagai Keputusan Bahasa) menyatakan bahwa Tetum resmi adalah variasi bergengsi dari bahasa Tetum yang akan diadopsi sebagai bahasa standar. Ketika dilihat sebagai wacana, keputusan itu mengambil simbolisme yang berjalan di luar mekanisme tata bahasa dan ejaan. Keputusan itu mengakui Tetum sebagai elemen penting dalam pembangunan bangsa dan dalam penegasan Identitas orang Timor Leste. Keempat prinsip dalam keputusan untuk merenovasi leksikon Tetum resmi adalah pernyataan identitas yang sangat politis. Mereka menyatakan bahwa:

(i) Tetum-Praça akan menjadi dasar dari bahasa sastra,

(ii) kata-kata pinjaman Indonesia harus dihindari dan akhirnya dihilangkan,

(iii) harus ada jarak Idiom yang dipengaruhi bahasa Indonesia yang mendukung Tetum-Terik, yang memiliki lebih sedikit pinjaman dari Bahasa Indonesia modern, dan

(iv) semua kata pinjaman harus sesuai dengan aturan ortografi.

Keputusan Bahasa lebih lanjut menetapkan bahwa Tetum Resmi harus digunakan dalam tiga domain status tinggi yaitu: sistem pendidikan, publikasi resmi, dan dalam komunikasi sosial. Prioritas harus diberikan kepada Tetum Resmi dan Portugis dalam gambar dan tanda publik. Bahasa Inggris dan bahasa Indonesia tidak boleh digunakan kecuali mereka disertai dengan teks dalam bahasa Tetum dan Portugis dengan keunggulan visual yang lebih besar. Namun dalam kenyataan sehari-hari di masyarakat penerapan kebijakan ini belum benar-benar terlihat.

Sementara itu UU Dinas Sipil No. 8/2004 mewajibkan publik pegawai untuk menggunakan bahasa resmi dalam administrasi publik. Hukum ini berlaku untuk Angkatan Bersenjata dan Kepolisian, Kantor Presiden Republik, Parlemen Nasional, dan Pengadilan. 
Sedangkan The Language Directive mengharuskan setiap aktor pengadilan untuk menggunakan bahasa resmi dalam korespondensi, permintaan dan penerimaan dokumen resmi. Dokumen yang tidak dikirim dalam bahasa resmi harus dikembalikan dan diberikan tenggang waktu delapan hari untuk pengiriman ulang dalam bahasa resmi.

Kerangka Kebijakan Pendidikan untuk 2004-2008 menetapkan tujuan dan prioritas untuk pendidikan. Tujuannya termasuk mempercepat pengenalan Portugis sebagai media pengajaran dan kebangkitan kembali penggunaan bahasa Tetum di sekolah-sekolah. Kebijakan kurikulum mengamanatkan penggunaan bahasa Portugis sebagai media instruksi dari Kelas 1 hingga 6 (SD). Portugis sebagai subjek mata pelajaran diperkenalkan di kelas menengah pertama pada tahun 2005. Sebaliknya Bahasa Indonesia ditarik dari kurikulum di sekolah dan universitas nasional. Kerangka kurikulum ini merupakan pendekatan transisi untuk pengajaran dan pembelajaran bahasa resmi.

Dalam konstitusi RDTL disinggung juga mengenai bahasa kerja. Bahasa yang dimaksud adalah bahasa Indonesia dan bahasa Inggris sebagaimana bunyi pasal 159," Bahasa Indonesia dan Bahasa Inggris merupakan bahasa-bahasa kerja yang digunakan dalam Pemerintahan Umum, sepanjang diperlukan". Terkait dijadikannya bahasa Inggris sebagai salah satu bahasa kerja, sekalipun jarang sekali digunakan secara riil di masyarakat tapi tidak menyurutkan Amerika Serikat berperan dalam pengembangan bahasa Inggris di negara ini dengan bekerjasama dengan UNTL mendirikan Uma Amerika di UNTL. Uma Amerika ini menyediakan pusat akses gratis kepada Warga Negara Timor-Leste untuk mengetahui tentang budaya Amerika serta mempromosikan inovasi dan pertukaran informasi yang terbuka antara Amerika Serikat dan Timor-Leste termasuk mendukung pengajaran Bahasa Inggris di Timor-Leste. Selain pihak pemerintah ada juga pihak swasta yang ikut berperan misalnya, Lorosa'e English Language Institute (LELI) yang menyediakan kursus untuk Bahasa Portugis, Bahasa Tetum dan Bahasa Inggris, juga dari Futuru Hahu Ohin (FHO) yang didirikan 2 tahun lalu ini menyediakan kursus bahasa untuk Bahasa Portugis dan Bahasa Inggris.

Pengembangan Bahasa Indonesia sendiri dilakukan di berbagai lembaga pemerintah dan swasta di Timor-Leste. Selain Pusat Budaya Indonesia (PBI) yang melaksanakan pengajaran Bahasa Indonesia melalui kerjasama dengan PPSDK. Selain itu Lembaga Pendidikan Annur selain sebagai lembaga pendidikan formal juga merupakan lembaga pendidikan agama Islam di Kota Dili, Timor-Leste juga melaksanakan pembelajaran Bahasa Indonesia. Lembaga ini menyediakan fasilitas pengajaran Bahasa Indonesia untuk diaspora Indonesia di Timor-Leste. Pengajaran Bahasa Indonesia yang dikelola oleh KBRI bekerjasama dengan PPSDK pada tahun 2018 mulai masuk pada sekolah-sekolah SMA/SMK dimana sebelumnya hanya pada beberapa perguruan.

Pengajaran Bahasa Indonesia pada tingkat SMA/SMK di mulai pada 13 sekolah SMA/SMK di Distrik Ermera, kemudian akan dilanjutkan pada 16 SMA/SMK di Distrik Baucau, Timor-Leste. Jika sekolah-sekolah pada kedua distrik mulai melaksanakan pengajaran Bahasa Indonesia, maka total lembaga yang pengajarkan Bahasa Indonesia di Timor-Leste berjumlah: 29 SMA/SMK dan 4 lembaga pendidikan tinggi (Universitas da Paz, Universitas Crystal, East Timor-Coffee Institute, Universitas Crystal, dan Institute of Business). Sedangkan pengembangan bahasa China mulai dirintis oleh Universitas Guangxi Normal University baik dengan penawaran kuliah di China ataupun dengan mendirikan Chinese Language and Culture Center bekerjasama dengan universitas/institut lokal yang ada di Timor Leste.

Observasi lapangan dilaksanakan dengan meliputi area pengamatan seperti; 1. Jalan-jalan protokol dan perumahan, 2. Pusat kegiatan ekonomi seperti terminal, pasar, pertokoan, mall/supermercado dan perkantoran, 3. Pusat kegiatan pendidikan seperti sekolah dan universitas, 4. Pusat aktivitas/berkumpulnya orang seperti warung makan, tempat wisata, pantai. dan 5. Gedung pemerintahan dan tempat-tempat milik negara.

Berdasar hasil observasi lapangan di titik-titik sebagaimana telah disebutkan bahasa yang digunakan untuk berkomunikasi secara oral antar anggota masyarakat didominasi dengan menggunakan bahasa Tetum. Bahkan ditempat-tempat formal seperti perkantoran, sekolah, dan universitas bahasa yang digunakan pun adalah bahasa Tetum, sedangkan bahasa Portugis meski juga berfungsi sebagai bahasa resmi dan diinstruksikan sebagai bahasa pengantar pendidikan namun porsi pemakaiannya hampir tidak ditemukan. Sedangkan bahasa Indonesia digunakan dalam suatu komunikasi hanya jika penanya memulai percakapan dengan bahasa Indonesia. Sementara bahasa Inggris digunakan dalam level yang sangat terbatas, terutama hanya di kantor-kantor NGO/LSM Internasional, perlu diketahui di Timor Leste terdapat 
setidaknya 402 NGO yang beroperasi dan 122 adalah NGO internasional (UNDP, 2006). Meski dalam konstitusinya bahasa Indonesia dan Inggris ditetapkan sebagai bahasa kerja di Timor Leste namun hasil pengamatan dilapangan pemakaian Tetum lebih mendominasi.

Demikian pula dalam ranah tulis seringkali ditemukan antara praktik yang berbeda dengan aturan yang ditetapkan pemerintah, bahkan seringkali terjadi pencampuradukan antara dua bahasa atau lebih. misalnya dalam undangan terkait kegiatan kampus masih ditemukan penggunaan bahasa Portugis dan Tetum, dalam dokumen tertentu masih ditemukan pencampuran pemakaian bahasa Indonesia dengan bahasa Inggris.

Pada ranah publik nama-nama jalan, gang, rambu-rambu, dan lanskap umum 100\% menggunakan bahasa Tetum (serapan dari Portugis) atau nama-nama tokoh. Nama-nama identitas kantor pemerintahan menggunakan bahasa Portugis sementara nama sekolah atau universitas menggunakan bahasa Portugis atau bahasa inggris. Pada level tertentu bahasa Indonesia masih digunakan terutama dalam lingkup perdagangan, pengumuman/pemberitahuan, ekspresi seni seperti dalam bentuk sticker di angkutan umum, motor dan sebagainya.

Salah satu hal yang juga tak bisa luput dari perhatian adalah konten-konten yang terdapat di gedung Arsip dan Museum Perlawanan Rakyat Timor (Resistencia Timorensie/Resistensia Timorense). Nampaknya oleh generasi Timor Leste yang masih menjadi elite politik sekarang bangsa Indonesia masih distigma sebagai bangsa penjajah dengan berbagai konten baik dalam bentuk arsip ataupun visual, sementara masa penjajahan Portugis yang lebih dari 450 tahun kurang ditampilkan (jika tidak bisa dikatakan 'disamarkan'). Hal itu tentu sangat mempengaruhi pola pikir generasi-generasi selanjutnya. Padahal secara data dan fakta 24 tahun masa Indonesia sangat berbeda jauh dengan 450 tahun di bawah Portugis, misalnya dalam hal jumlah pembangunan infrastruktur terutama jalan dan fasilitas pendidikan.

Kerancuan antara aturan dan praktik penggunaan bahasa terjadi di banyak tempat dan waktu. Hal itu dipengaruhi beragam faktor, salah satu faktor utamanya adalah adanya kesenjangan antara aturan yang belum mapan dengan kondisi kemampuan berbahasa di lapangan (masyarakat). Belum adanya standarstandar pelaksanaan bagi pelaksana seringkali membuat masing-masing institusi melaksanakan kebijakan atas inisiatif sendiri contohnya; sebuah universitas mewajibkan para mahasiswanya menulis skripsi dengan bahasa Tetum atau Portugis, sementara ada juga universitas yang mewajibkan dengan bahasa Indonesia, dan seterusnya. Banyak aturan yang belum dapat menjangkau penyelenggara pendidikan swasta, sementara jumlah sekolah negeri masih sangat terbatas.

Hal yang unik terkait kondisi sosial politik Timor Leste adalah bahwa hampir semua profesi diperbolehkan ikut aktif berpolitik termasuk para akademisi. Hal tersebut tentu sangat berpengaruh kepada penyelenggaraan pendidikan karena mereka cenderung melakukan politik praktis demi menjaga kepentingan yayasan atau institusi pendidikannya. Bahkan ditemukan banyak akademis yang mengajukan cuti lebih dari satu bulan agar dapat berpartisipasi dalam kampanye ketika diadakan pemilihan parlemen pada April-Mei 2018.

Beberapa pihak berhasil diwawancarai baik secara formal ataupun informal dalam rangka pengumpulan informasi seutuhnya. Para informan diambil dengan berlatar pada penggolongan usia dan profesi sebagai bentuk yang mewakili masa-masa yang pernah dialami yaitu; masa Portugis $(<1975)$, masa Indonesia (1975 - 1999), masa merdeka (1999—-sekarang). Karena dengan usia yang berbeda terlihat pula cara pandang mereka yang terbentuk berdasar pengalaman hidup dalam kerangka perkembangan Timor Leste semenjak masa Portugis, masa Indonesia, dan masa kemerdekaan. Oleh karena itu informan diambil berdasar tiga golongan tersebut.

Secara umum hasil dari wawancara tentang bahasa Indonesia di Timor Leste dengan beberapa sumber dapat disimpulkan sebagai berikut;

1. Oleh sebagian golongan tua (usia 54 ke atas) bahasa Indonesia masih distigmakan sebagai bahasa Penjajah, terutama jika dihubungkan dengan aturan di masa Indonesia dimana bahasa yang wajib digunakan di ruang publik dan formal adalah bahasa Indonesia, sedangkan pemakai bahasa Portugis dengan mudah dianggap sebagai bagian dari pemberontak (terutama Fretilin), karena memang sebagian besar tokohnya menggunakan bahasa Portugis sebagai simbol perlawanan. Namun mereka juga menyadari ketergantungan kepada Indonesia tidak dapat dikesampingkan dalam menata masa depan Timor Leste. 
2. Pasal 13 konstitusi RDTL merupakan gambaran kegamangan pemerintah Timor Leste karena mereka menyadari bahwa bahasa asli mereka (Tetum) belum begitu kuat baik secara sosial maupun politik internasional, salah satu sebabnya adalah dengan masih sangat terbatasnya kosakata yang dimiliki.Sehingga dipilihlah bahasa Portugis sebagai bahasa resmi kedua apalagi kosakata dan dasar kebahasaan Tetum banyak menyerap dari bahas Portugis. Alasan tersebut dapat dipahami baik dari sisi kepentingan politik Internasional mereka maupun sebagai penegas dan pembeda terhadap 'mantan' penjajahnya, Indonesia. Selain itu dengan menetapkan bahasa Portugis sebagai bahasa resmi, secara kesejarahan mereka tidak terputus dengan Portugis sekaligus merupakan akses dalam menjadi bagian dari CPLP (Kelompok Negara Berbahasa Portugis) sehingga akses ke Uni Eropa pun akan lebih mudah.

3. Pengakuan bahasa Indonesia sebagai bahasa kerja, selain bahasa Inggris adalah kompromi terhadap realita yang ada di masyarakat Timor Leste karena disamping secara ekonomi $80-90 \%$ pasokan barang berasal dari Indonesia, masih banyak pula masyarakat Timor Leste yang masih mempunyai hubungan kekeluargaan dengan warga negara Indonesia. Secara budaya pun masyarakat Timor Leste juga masih akrab dengan beragam siaran media dari Indonesia. Sehingga meski banyak sekolah dasar dan menengah sudah tidak mengajarkan bahasa Indonesia namun anak-anak Timor Leste belajar bahasa Indonesia melalui siaran-siaran dari media Indonesia.

4. Generasi yang berusia 25-54 tahun beranggapan adalah salah jika pemerintah ingin 'menjauhkan' dari (bahasa) Indonesia. Karena selain ketergantungan ekonomi terhadap Indonesia, generasi Timor Leste juga sangat membutuhkan bahasa Indonesia terutama dalam mendapatkan akses pendidikan tinggi yang lebih mapan sekaligus terjangkau yang banyak terdapat di perguruan tinggi Indonesia dibandingkan jika harus ke Australia, Brazil, atau pun Portugal.

5. Generasi baru Timor Leste (usia 15-54 tahun) sebagian besar sudah tidak mempermasalahkan masa lalu antara Indonesia dengan Timor Leste. Bahkan sebagian dari mereka juga beranggapan bahwa apa yang terjadi pada Timor Leste di masa lalu adalah buah dari perbuatan sebagian masarakat Timor Leste sendiri. Mereka sangat mendambakan bahwa bahasa resmi Timor Leste cukup Tetum, sedangkan bahasa Portugis cukup didudukkan sejajar dengan bahasa lainnya (Indonesia dan Inggris). Dalam pandangan mereka bahasa Indonesia sejauh ini adalah bahasa yang masih mereka kuasai yang dapat mengakomodasi kebutuhan berekspresi.

\section{B. Peta Potensi dan Hambatan Pengembangan Bahasa Indonesia di Timor Leste}

Pemetaan terhadap potensi dan hambatan dalam rangka pengembangan bahasa Indonesia di Timor Leste tidak bisa dilepaskan dari nilai kesejarahan hubungan Indonesia dengan Timor Leste, nilai geopolitik, dan nilai sosial budaya sehingga dapat dijadikan dasar dalam merancang strategi pengembangan bahasa Indonesia di negara tersebut. Sebagai negara tetangga sekecil apapun Timor Leste dibanding Indonesia namun mereka tetap menjadi aspek yang perlu diperhitungkan bagi kepentingan Indonesia di masa datang.

Diplomasi kebudayaan melalui pembelajaran bahasa Indonesia bernilai strategis sebagai bentuk diplomasi lunak dan gerbang dalam menjalin persahabatan dan perbaikan citra Indonesia di Timor Leste. Hubungan kedua negara dan perkembangan terkini dapat dijadikan bahan pertimbangan dalam penyusunan strategi pengembangan bahasa Indonesia di wilayah ini disamping data-data lain. Pengetahuan mengenai sebaran pemakaian bahasa dapat dijadikan pertimbangan dalam rangka penyusunan strategi penyebaran bahasa Indonesia di Timor Leste.

1. Potensi Pengembangan;

a. Sebagian besar masyarakat Timor Leste masih memahami bahasa Indonesia, namun bagi generasi yang tumbuh dan besar setelah Timor Leste memilih merdeka mereka mulai tidak mengenal apalagi menggunakan bahasa Indonesia.

b. Indonesia memiliki gedung megah setinggi 7 lantai (PBI) yang dapat lebih dimaksimalkan fungsinya, terutama bagi diplomasi budaya Indonesia di timor Leste. Berdasar beberapa wawancara terutama kepada kalangan pelajar/mahasiswa bahkan masih banyak yang belum tahu apa dan dimana itu PBI.

c. Media-media Indonesia terutama televisi yang masih dapat dijangkau oleh masyarakat Timor Leste, namun berdasar informasi yang di dapat media-media tersebut hanya dapat diakses di wilayah Dili (kota) dan hanya melalui jaringan parabola saja. 
d. Ketergantungan ekonomi Timor Leste terhadap Indonesia, terutama dalam hal pasokan kebutuhan sehari-hari dari wilayah Indonesia namun, besar kemungkinan lambat laun hal tersebut akan berkurang terutama dengan banyak masuknya bahan-bahan dari negara lain terutama New Zealand, Portugal, dan Cina.

e. Keunggulan Indonesia dibanding negara lain terutama dalam akses pendidikan yang lebih terjangkau,baik jarak ataupun biaya dibanding dengan dengan negara tujuan lain seperti Australia, Brazil, ataupun Portugal.

f. Struktur bahasa Indonesia yang sederhana sehingga lebih mudah dipelajari dibanding bahasa asing lain yang ada di Timor Leste seperti; Portugis dan Inggris.

g. Masih banyaknya diaspora Indonesia yang bekerja ataupun tinggal di Timor Leste.

h. Masih kurangnya literatur-literatur dan bahan pelajaran di Timor Leste, memberi peluang Indonesia untuk memasukkan bahan-bahan kebutuhan tersebut, tentu saja dengan pengantar bahasa Indonesia.

i. Adanya komunitas diaspora Indonesia yang cukup besar sehingga berpotensi membantu dan mempertahankan pemakaian bahasa Indonesia di Timor Leste. Sehingga perlunya pelibatan komunitas tersebut oleh pemerintah Indonesia dalam mewujudkan Internasionalisasi bahasa Indonesia khususnya di Timor Leste.

j. Banyaknya peminat masakan Indonesia yang disediakan oleh warung/restoran juga bisa dimanfaatkan dalam sosialisasi bahasa Indonesia.

k. Kekayaan kosakata dan keluwesan bahasa Indonesia sebagai media pengungkapan ekspresi seni dapat juga ditonjolkan dalam menarik minat masyarakat Timor Leste mempelajari bahasa Indonesia.

1. Diputuskannya dalam konstitusi RDTL pada pasal 159 bahwa bahasa Indonesia sebagai salah satu bahasa kerja bisa dimanfaatkan semaksimal mungkin dalam mendorong masyarakat Timor Leste mempelajari bahasa Indonesia terutama ragam ilmiah atau formal.

m. Keinginan Timor Leste agar dapat tergabung dalam ASEAN juga dapat dimanfaatkan dalam rangka mendapatkan akses pendukung penyebaran bahasa Indonesia di Timor Leste.

2. Potensi hambatan;

a. Pasal 13 dalam konstitusi RDTL dan beberapa peraturan pemerintah yang mengutamakan penguasaan bahasa Portugis terutama bagi para pendidik dan pekerja sektor formal sedikit banyak juga mengurangi minat atau kesempatan masyarakat Timor Leste untuk mempelajari bahasa Indonesia.

b. Masih adanya sentimen atau stigma sebagian golongan masyarakat yang menganggap Indonesia sebagai "penjajah" sehingga mempengaruhi pula sikapnya terhadap segala yang berbau Indonesia termasuk bahasa Indonesia.

c. Adanya negara lain yang juga berminat mengembangkan bahasanya di Timor Leste seperti; Portugal, Australia/Amerika, Cina, dan lainnya.

d. Kecenderungan yang terjadi dikalangan anak muda saat ini yang lebih memilih mempelajari bahasa Portugis, Inggris, atau Korea karena terkait dengan cita-cita agar dapat bekerja atau mencari penghidupan lebih layak.

e. Banyak generasi muda yang belum menemukan apa arti penting mempelajari bahasa Indonesia bagi mereka. Selain itu masih sedikit sekali generasi muda terutama yang lahir dan besar setelah merdeka yang mengenal Indonesia secara lebih mendalam.

f. Berita-berita media Indonesia yang seringkali memberitakan hal-hal negatif yang terjadi seperti kasus-kasus kriminal dan sebagainya banyak mempengaruhi pandangan orang muda Timor Leste sehingga mereka menganggap Indonesia adalah negara tidak aman dan tidak demokratis. Hal tersebut juga berlaku terhadap berita-berita hoax berbau politis yang sering di share oleh orang Indonesia kebanyakan di media sosial.

g. Pengetahuan mengenai Indonesia secara umum masih minim pada generasi muda karena akses media yang masih terbatas sehingga seringkali hanya terbatas mengenai Bali dan sekitarnya saja. 
h. Media sosial semacam Facebook seringkali didominasi oleh pihak-pihak yang kontra Indonesia seperti page; Papua Blood dan sebagainya yang cenderung mendiskreditkan Indonesia tanpa anda berita berimbang/kounter berita dari Indonesia.

i. Strategi penyebaran yang masih berfokus hanya di kota Dili.

\section{Simpulan}

Para elit Timor Leste menyadari mereka diapit oleh tiga raksasa dengan beda bahasa; Indonesia, Australia, dan Portugis. Situasi kebahasaan yang ada di Timor leste dapat dikaji dalam dua ranah yang saling berkaitan yaitu; pada ranah makro (negara) dan mikro (komunitas/masyarakat). Sebagai sebuah negara baru yang mengalami sejarah panjang kolonialisme dan multilingualisme sangat wajar jika pemerintahnya mencoba menemukan identitas sendiri sebagai pemertahanan eksistensi kebangsaannya. Kedekatan sejarah dengan Portugis yang telah merasuk jauh dan telah menjadi bagian hidup tentu sangat berpengaruh dan kedekatan geografis dan ekonomis dengan Indonesia dan Australia juga tidak dapat dinafikan begitu saja. Sehingga para pendiri negara ini mengambil 'jalan tengah' dalam mengakomodir tegangan fakta sejarah yang ada dengan kehendak merekonstruksi identitas sebagai sebuah bangsa merdeka, salah satunya adalah dengan dipilihnya Portugis sebagai salah satu bahasa resmi bersama salah satu bahasa lokal yang paling populer pemakaiannya (Tetum), sedangkan bahasa Indonesia dan Inggris dijadikan sebagai bahasa Kerja. Hal itu tercantum dalam pasal 13 dan pasal 159 konstitusi negara Timor Leste. Meski bahasa resmi utama adalah bahasa Tetum (salah satu bahasa lokal) dan bahasa lokal lainnya ditetapkan sebagai bahasa nasional yang dilindungi namun bangsa ini juga menyadari bahwa bahasa Tetum belum mampu mengakomodir kebutuhan dan perkembangan jaman karena keterbatasan kosakata dan belum adanya kaidah-kaidah kebahasaan yang dapat dijadikan pedoman.

Kecenderungan sikap positif pemerintah Timor Leste terhadap bahasa Portugis mengungguli terhadap bahasa asing lainnya termasuk bahasa Indonesia. Salah satu yang nyata terlihat adalah penetapan standar bahasa baku dalam bahasa Tetum adalah bahasa Tetum dengan serapan kosakata dari bahasa Portugis, sedangkan serapan dari bahasa Indonesia dianggap tidak baku, dan lambat laun akan dihilangkan. Meskipun aturan tersebut belum tentu berlaku selamanya, karena selain dinamika politik di negara ini sangat cair, banyak kalangan terutama akademisi tidak setuju dengan langkah pemerintah yang mencoba 'menjauhkan diri' dari bahasa Indonesia.

Gambaran Indonesia sebagai bahasa para 'penjajah' dalam narasi sejarah Timor Leste juga berperan dalam stagnasi pemakaian bahasa Indonesia. Hal tersebut bisa dipahami karena pihak-pihak yang berkuasa di pemerintahan saat ini mayoritas masih didominasi oleh golongan pro kemerdekaan (Fretilin), dan di level masyarakat pun pendukung partai Fretilin masih mendominasi pada setiap pemilihan umum meskipun ketika berada di parlemen mereka seringkali dikalahkan oleh para koalisi oposisi. Ketika era 'perjuangan kemerdekaan' tersebut perlawanan dengan pembentukan identitas melalui bahasa juga dilakukan, kewajiban menggunakan bahasa Indonesia yang dijalankan oleh pemerintah Indonesia dilawan oleh para pejuang Fretilin dengan menggunakan bahasa Portugis sebagai alat komunikasi sekaligus simbol perlawanan. Ketika telah merdeka langkah tersebut di formalkan dengan hukum positif melalui konstitusi.

Langkah penetapan bahasa Portugis sebagai bahasa resmi juga tak lepas juga dari posisi yang ingin diambil Timor Leste yang tergabung dalam CPLP (kelompok negara-negara berbahasa Portugis), disamping peran Portugis dan Brazil sangat signifikan dalam mendukung kelangsungan negara Timor Leste selama ini tak bisa dikesampingkan. Selain itu dengan hubungan erat dengan Portugis otomatis memudahkan dalam berhubungan dengan negara Uni Eropa lainnya. Dari segi makro (negara) pelaksanaan Internasionalisasi bahasa Indonesia di Timor Leste perlu menjalin komunikasi dan kerjasama dengan instansi-instansi berwenang berikut ini dalam rangka menunjang keberhasilan program; 1 . Dewan Menteri (yang terdiri dari; Perdana Menteri, Deputi Perdana Menteri, dan menteri-menteri yang ada di kabinet). 2. Kementerian Pendidikan, Kebudayaan, Pemuda dan Olah Raga (Ministerio de Cultura, Juventude e Esporto/MECYS). 3. Dewan Hakim Agung, (dengan dibantu Kementerian Keadilan). 4. 88 anggota Majelis Konstituen (sekarang menjadi Parlemen nasional). 5. Institut Linguistik Nasional (Instituto Nacional Linguistica/INL).

Sementara itu ada beberapa kebijakan yang juga perlu menjadikan periksa bagi penyusunan strategi pengembangan bahasa Indonesia di wilayah Timor Leste yaitu; 1. Konstitusi Nasional atau The National 
Constitution of 2002. 2. Keputusan Bahasa atau Government Decree No. 1 of 2004: Orthographical Standard of the Tetum Language. 3. UU Dinas Sipil No. 8/2004 atau Civil Service Law No. 8 of 2004. 4. Arahan Kebahasaan atau The Language Directive of 2004. 5. Kerangka Kebijakan Pendidikan untuk 20042008/The Education Policy Framework for 2004-2008.

Jika dibandingkan dengan 3 bahasa utama lainnya di Timor Leste (Tetum, Portugis, Inggris) posisi bahasa Indonesia sedikit kurang menguntungkan, apalagi jika ditambah dengan beban narasi sejarah Timor Leste yang memposisikan Indonesia sebagai 'penjajah'. Pasal 13 dan 159 konstitusi Timor Leste memperkuat asumsi tersebut. Demikian juga dengan 4 kebijakan lainnya. Penurunan fungsi dan peran bahasa Indonesia juga terindikasi mulai ada, karena jumlah penduduk Timor Leste yang tidak bisa berbahasa Indonesia pada tahun 2010 sejumlah 38\% dari total penduduk meningkat menjadi $44 \%$ pada tahun 2015. Sedangkan jumlah pemakai (orang yang menguasai baik baca, tulis, dan berbicara) bahasa Indonesia cenderung stagnan (kisaran 36\%) padahal pada sisi lain jumlah penduduk bertambah lebih dari 100.000 orang. Hal tersebut tak lepas dari berbagai kebijakan yang diambil oleh pemerintah Timor Leste sebagaimana disinggung sebelumnya.

Jika ditinjau dari segi mikro (komunitas/masyarakat) bahasa Indonesia masih berterima dan dianggap perlu dikuasai meski beberapa golongan masyarakat (terutama golongan tua dan di wilayah rural) masih memandang bahasa Indonesia sebagai bahasa penjajah. Namun rata-rata generasi usia menengah (yang pernah merasakan pendidikan Indonesia) dan generasi muda menganggap mempelajari bahasa Indonesia adalah penting, terutama karena salah satu akses ekonomi dan pendidikan yang paling realistis dan terjangkau bagi sebagian besar masyarakat Timor Leste adalah ke Indonesia. Selain itu ketersediaan kebutuhan lain seperti media, hiburan dan lainnya juga jauh lebih mapan Indonesia.

Pada level realita di lapangan memang masih banyak orang yang mampu berbahasa Indonesia namun kini penggunaan bahasa Indonesia (dalam percakapan) hanya jika lawan bicara memulai dengan bahasa Indonesia saja (penggunaan pasif). Hal itu pun didominasi oleh para warga yang pernah mengenyam pendidikan masa Indonesia ataupun masih berdarah Indonesia. Sedangkan generasi muda Timor Leste yang besar setelah merdeka mayoritas sudah tidak memahami bahasa Indonesia, dan jikapun memahami kebanyakan belajar secara otodidak melalui tayangan televisi sehingga terbatas pada aspek oral saja.

Beberapa langkah yang dapat dilakukan Indonesia dalam rangka mendorong pengembangan bahasa Indonesia di Timor Leste adalah:

1) Terus menerus memperbaiki citra Indonesia melalui beragam soft diplomasi seperti kerjasama even-even kebudayaan, pengajaran terutama tidak hanya dengan level universitas namun juga dengan level sekolah-sekolah dibawahnya.

2) Keberadaan teks-teks pelajaran ataupun buku-buku pengayannya sangat berperan dalam menjaga interaksi antara generasi Timor Leste dengan pengetahuan tentang (bahasa) Indonesia.

3) Lebih memaksimalkan peran PBI sebagai 'corong' Indonesia di Timor Leste.

4) Perlunya kerjasama penyusunan kamus dwibahasa Indonesia-Tetum, karena banyak kasus ditemukan ketika mahasiswa kesulitan dalam memahami pelajaran bahasa Indonesia mereka malah menggunakan alat bantu kamus Indonesia-Inggris.

5) Pertukaran pelajar atau kegiatan studi banding antar kedua negara lebih intensif serta berskala luas akan membantu pemahaman kondisi nyata kedua negara.

6) Pelibatan diaspora Indonesia dalam percepatan Internasionalisasi bahasa Indonesia sangat diperlukan, karena hingga kini bahkan WNI sendiri banyak yang belum mengetahui perihal Internasionalisasi bahasa Indonesia.

7) Dukungan kepada komunitas atau tokoh yang setia menggunakan bahasa Indonesia (misalnya para dai yang berceramah dengan bahasa Indonesia, para pastor yang dalam pelaksanaan ibadah menggunakan bahasa Indonesia).

8) Pihak swasta, terutama dalam hal penyelenggaraan pendidikan juga mempunyai peran besar dalam membantu penyebaran bahasa Indonesia karena mereka mempunyai independensi dalam menyusun kurikulumnya dan seringkali peraturan-peraturan pemerintah Timor Leste belum mampu menekan pihak-pihak tersebut.

9) Dukungan bahan-bahan bacaan/literasi berbahasa Indonesia juga sangat strategis dalam mendukung pengembangan bahasa Indonesia di Timor Leste. 
10) Pemanfaatan media seperti radio juga masih vital dibanding televisi sehingga dapat dijadikan alternatif media diplomasi kebudayaan Indonesia. Selain itu pemanfaatan posisi lokasi gedung PBI yang strategis secara praktis dapat juga dijadikan media 'iklan' tentang Indonesia misalnya, dengan pemasangan videotron/monitor raksasa luar ruang yang menayangkan tentang Indonesia secara terus menerus sehingga publik dapat menyaksikan secara langsung setiap melalui gedung tersebut.

Demikian kajian mengenai kondisi dan situasi kebahasaan di Timor Leste. Hasil kajian ini masih jauh dari sempurna terutama jika terkait data observasi lapangan dan wawancara karena adanya keterbatasan area pengamatan maupun kalangan yang terlibat sebagai informan. Oleh karena itu sebaiknya pengambilan data dilakukan lebih luas dan mendalam lagi baik terkait area maupun kalangan yang dilibatkan.

\section{Ucapan Terima Kasih}

Terima kasih penulis ucapkan kepada; Prof. Emi Emilia, M. Ed., Ph.D, dan Dr. Joni Endardi, M. Hum., dan Dony Setiawan, M.Pd selaku pimpinan di PPSDK yang telah memberi kesempatan penulis berperan dalam program BIPA di Timor Leste. Atase Pendidikan RI di Timor Leste, Bapak Sedercor Melatunan dan seluruh staf KBRI dan PBI atas bantuan dan fasilitas selama di Dili.

\section{Daftar Rujukan}

Census Atlas. (2006). Timor-Leste census of population and housing. Dili, RDTL: National Statistics Directorate \& UNFPA.

https://www.cia.gov/library/publications/the-world-factbook/

Hull, Geoffrey. (1998). The languages of Timor 1772-1997: a Literature Review. Studies in Languages and Cultures of East Timor 1:1-38.

Timor Leste Goverment. (2015). Livru Sensus. Dili: United Nations Children's Fund (UNICEF), United Nations Population Fund (UNFPA).

MECYS [Ministry of Education, Culture, Youth and Sport]. (2004). Education Policy 2004-2009. Dili, RDTL: MECYS.

Moeliono, Anton M. (1985). Pengembangan dan Pembinaan Bahasa: Ancangan Alternatif di dalam Perencanaan Bahasa. Jakarta: Djambatan.

National Directorate of Statistics. (2006). Census of population and housing: National priority tables. Dili, RDTL: National Directorate of Statistics and UNFPA.

UNDP (2006). The path out of poverty. Dili: United Nations Development Programme. 